\title{
EVALUASI PENYELENGGARAN MADRASAH TSANAWIYAH SATU ATAP (MTS-SA) SABILUL MUTTAQIEN PAMEKASAN JAWA TIMUR
}

\author{
Munawiroh \\ Peneliti Puslitbang Pendidikan Agama Dan Keagamaan \\ Badan Litbang Diklat Kementerian Agama RI \\ Jl. MH Thamrin No. 06 Jakarta Pusat \\ Email: mun.asrori@gmail.com
}

\begin{abstract}
This article is a result of evaluative research of the implementation of Madrasah Tsanawiyah Satu Atap (MTs SA) Sabilul Muttaqien Pamekasan in Madura. The research is focused on how the development of education access on its school, the service availability, the service affordability, the student development and madrasah management. The method used in this research is evaluation method with qualitative approach. The research result concludes that the main facilities of the madrasah are available sufficiently, only the education means which not sufficient enough. On the madrasah management, it is also sufficed both in terms of educators and education personnel in accordance with the needs and academic qualifications as well as thier competencies. From management point of view, this madrasah has already had plans of activity programs, priority scales and five yearly programs. The mechanism of activity program implementations has been arranged on their organization structures and duties, as well as the scheduled evaluation for the activities. To guarantee the transparency and community' involvement, those programs are arranged with involving the stakeholders element.
\end{abstract}

Kata Kunci: Madrasah Tsanawiyah Satu Atap (MTs SA), education access, management of madrasah education

\begin{abstract}
Abstrak
Artikel ini merupakan hasil penelitian evaluatif tentang Penyelenggaran Madrasah Tsanawiyah Satu Atap (MTs SA), Kasus pada Madrasah Tsanawiyah Satu Atap (MTs SA) Sabilul Muttaqien Pamekasan di Madura. Penelitiannya difokuskan pada bagaimana pengembangan akses pendidikan pada sekolah tersebut, meliputi ketersediaan layanan, keterjangkauan layanan, perkembangan siswa dan tata kelola madrasah. Metode yang digunakan dalam penelitian ini yaitu metode evaluasi dengan pendekatan kualitatif. Hasil penelitian menyimpulkan bahwa sarana utama madrasah sudah tersedia dengan cukup memadai, hanya sarana pendidikan yang belum memadai. Begitu pula untuk pengelolalaan madrasah sudah terpenuhi baik tenaga pendidik maupun tenaga kependidikan sesuai kebutuhan dan sesuai kualifikadsi akademik dan kompetensinya. Dari segi manajemen, madrasah ini sudah memiliki perencanaan program kegiatan, skala prioritas dan program kegiatan jangka lima tahunan. Untuk mekanisme penyelenggaraan program kegiatan telah disusun struktur organisasi dan uraian tugasnya, serta evaluasi kegiatan terjadwal. Untuk menjamin transparansi dan keterlibatan masyarakat, program-program tersebut disusun dengan melibatkan unsur pemangku kepentingan (stakeholders).
\end{abstract}

Key word: Madrasah Tsanawiyah Satu Atap (MTs SA), akses pendidikan, tata kelola pendidikan madrasah

Naskah diterima 30 September 2013. Revisi pertama, 27 Oktober 2013. Revisi kedua, 15 November 2013 dan revisi terahir 2 Desember 2013. 


\section{PENDAHULUAN}

Krisis ekonomi berdampak terhadap penyelenggaraan pendidikan. Dampak pertama adalah penurunan kemampuan finansial pemerintah. Dampak kedua adalah penurunan kemampuan orang tua untuk membiayai pendidikan dan kemampuan masyarakat untuk berperan serta dalam pembiayaan pendidikan,. Akibatnya kemampuan sekolah dalam menyelenggarakan pendidikan dan kemampuan orang tua dalam menyekolahkan anaknya menurun.

Komitmen pemerintah dalam pendidikan tidak berubah, meskipun dalam kondisi krisis ekonomi. Namun demikian, Pemerintah tetap ingin berusaha dan mempertahankan kualitas dan kuantitas pendidikan dasar melalui program bantuan pihak lain seperti Bank Dunia, Asian Development Bank (ADB), United Nations Children's Fund (UNICEF), dengan tujuan untuk meningkatkan kuantitas dan kualitas terutama pendidikan siswa.

Program Pendidikan dasar 9 Tahun untuk mewujudkan suatu masyarakat Indonesia yang terdidik minimal memiliki pengetahuan dan keterampilan dasar yang esensial. untuk melanjutkan ke jenjang pendidikan yang lebih tinggi atau dijadikan bekal untuk menjalani hidup dan menghadapi kehidupan dalam masyarakat.

Sehubungan hal tersebut di atas, pemerintah Australia dan pemerintah Indonesia, melalui Australia Indonesia Partnership for Basic Education Program (AI-BEP) merencanakan perluasan akses bagi siswa miskin di pedesaan untuk medapatkan kesempatan menyelesaikan pendidikan dasar 9 tahun. Untuk maksud ini akan dibangun sejumlah SLTP di seluruh Indonesia. Program penuntasan wajib belajar pendidikan dasar oleh Kementerian Agama menggunakan madrasah di lingkugan pesantren dan Madrasah Negeri Madrasah Tsanawiyah Negeri (MTsN) baru juga akan dibangun di Madrasah Ibtidaiyah Negeri (MIN) yang memenuhi kriteria.
Data EMIS-Depag menunjukkan bahwa enrolmen pada MTs di Pesantren meningkat sampai 10,5\% per tahun dibandingkan dengan MTs di luar Pesantren, yang hanya 3,6\%. Pada pesantren besar terjadi subsidi silang antara siswa dari keluarga kaya dan siswa dari keluarga miskin yang mengikuti pendidikan gratis. Sedangkan siswa MTsN senantiasa bertambah sebagaimana layaknya sekolahsekolah negeri lainnya.

Untuk itu dalam rangka memberikan layanan pendidikan bagi masyarakat baik pedalaman maupun karena terisolir dan sulit terjangkau, pemerintah khususnya Kementerian Agama telah bekerjasama dengan pemerintah Australia, melaksanakan pembangunan Madrasah Tsanawiyah Satu Atap (MTs-SA). MTs-SA adalah Madrasah Tsanawiyah (MTs) secara terpadu dengan madrasah Ibtidaiyah atau satuan pendidikan dasar formal sederajat lainnya di bawah naungan Kementerian Agama, pada pesantren, dan Madrasah Tsanawiyah Negeri (MTsN) secara terpadu dengan Madrasah Ibtidaiyah Negeri (MIN) di bawah naungan Kementerian Agama.

Untuk mengetahui efektifitas penyelenggaraan pendidikan Madrasah TsanawiyahSatu Atap (MTs-SA) perlu dilakukan evaluasi terhadap keseluruhan aspek internal maupun eksternalnya. Secara internal evaluasi dilakukan terhadap komponen yang langsung terlibat dalam program, sedangkan aspek eksternalnya mencakup kontribusi yang diberikan masyarakat di luar penyelenggara program, sehingga dapat diketahui hambatan, manfaat dan dampak penyelenggaraan program. Adapun sampel daripada penelitian ini adalah, MTs-SA Sabilul Muttaqien Desa Budagan, Pademawu, Pamekasan Jawa Timur.

Rumusan masalah yang diajukan dalam penelitian adalah: (1) bagaimanakah pengembangan akses pendidikan pada MTsSA Sabilul Muttaqien, (2) bagaimanakah tata kelola yang berlangsung di MTs-SA Sabilul Muttaqien, dan (3) partisipasi masyarakat 
dalam mendukung keberadaan MTs-SA Sabilul Muttaqien.

Tujuan dari penelitian ini adalah untuk mengetahui: (1) pengembangan akses pendidikan pada MTs-SA Sabilul Muttaqien, yang mencakup ketersediaan layanan, keterjangkauan layanan, (2) tata kelola yang berlangsung di MTs-SA Sabilul Muttaqien, yang mencakup aspek kepemimpinan, kemandirian dan transparansi, dan (3) partisipasi masyarakat dalam mendukung keberadaan MTs-SA Sabilul Muttaqien.

\section{Kerangka Teori}

\section{Evaluasi}

Evaluasi menurut Popham yang adalah proses pencarian, pengumpulan dan pengambilan data (informasi) yang diperlukan untuk memberikan pertimbangan apakah program yang sedang berjalan perlu diperbaiki, dihentikan atau diteruskan. ${ }^{1}$ Evaluasi bertujuan untuk mengetahui apakah program mencapai sasaran yang diharapkan. evaluasi adalah proses untuk mengumpulkan informasi secara sistematik, obyektif, dan terstruktur untuk memberikan keputusan terhadap sesuatu obyek. $^{2}$ Evaluasi adalah suatu proses yang sistematis untuk melakukan pengumpulan, analisis dan interpretasi terhadap informasi yang dapat menetapkan tingkatan pencapaian tujuan belajar dari pembelajar.

Dari devinisi di atas disimpulkan bahwa evaluasi merupakan suatu kegiatan yang dilakukan untuk memperoleh data/informasi secara kualitatif dan kuantitatif, sehingga dapat diperoleh suatu keputusan. Informasi tersebut digunakan untuk menilai seberapa jauh program telah berjalan sesuai yang direncanakan dengan jalan membandingkan beberapa kriteria yang telah ada sebelumnya.

W.James Popham. 1981. Modern Educational Evaluation. New Jersey: Prenctice Hall Inc.. p. 7.

2 Norman E. Grounlund and Robert L. Linn. 1990. Measurment and Evaluation in Teaching. New York: Mac Milan Publishing Company. p. 5.
Evaluasi Program Menurut Rutman, evaluasi program adalah penerapan metode-metode ilmiah untuk mengukur implementasi dan hasil program guna pengambilan keputusan. ${ }^{3}$ Dalam melakukan evaluasi program tidak bisa dilakukan secara serampangan, tetapi sistematis, rinci, dan menggunakan prosedur yang sudah diuji secara cermat. Dari pendapat tersebut disimpulkan bahwa evaluasi program adalah suatu upaya untuk mengumpulkan,menyusun, mengolah dan menganalisa fakta, data dan informasi untuk menyimpulkan harga, nilai, prestasi, kegunaan, manfaat mengenai sesuatu program, kantor, sekolah, organisasi atau lembaga dan lain-lain untuk dibuat kesimpulan sebagai landasan pengambilan keputusan tentang program tersebut, apakah dilanjutkan, direvisi atau dihentikan.

Evaluasi program mancakup empat komponen utama, yaitu: (1) Konteks, (2) Input, (3) Proses, dan (4) Output,. Kaufman menyebutkan beberapa model evaluasi yang sangat terkenal, antara lain: Scriven's, Formative-Sumative Model, CIPP Model, Stake's Countenance Model, Tyler's Goal Attainment Model, Provus,s Discrepancy Model, Scriven's Goal-free Model, Stake's Responsive Model. ${ }^{4}$ Dalam hal lain, keempat model evaluasi Stufflebeam tersebut dapat dipadukan dengan model-model evaluasi yang dikembangkan oleh beberapa ahli-ahli lain yang sudah dianggap baku dan standar, serta telah teruji kehandalannya dalam berbagai penerapan pendidikan. Jika kita memakai rumus evaluasi menurut Stufflebeam, dalam evaluasi terkandung delapan pengertian: ${ }^{5}$ (1) Process, merupakan serentetan kegiatan yang dilakukan secara terencana dan sistematis dengan mempergunakan prosedur dan metode

Leonard Rutman. 1984. Evaluation Research Methodology. New Delhi: Sege Publication India PVT. Ltd., 2 ed. p. 122.

${ }^{4}$ R. Kaufman \& S. Thomas. 1980. Evaluations Without Fear. Yow York: New Viewpoints. pp. 109-113.

${ }^{5}$ Soenarto Sapoetra. 1995. "Berbagai Model Evaluasi Program" Yogyakarta, Disampaikan Sebagai Materi Penataran Metodologi Evaluasi Program dalam Rangka Program Peningkatan Kualitas Peneliti. hh. 9-11. 
tertentu, dan bersifat berkesinambunag dan siklis, (2) Delineating, mengandung pengertian bahwa permasalahan yang akan dianalisis diungkapkan secara rasional, spesifik, dan dirumuskan secara jelas, (3) Obtaining, upaya memperoleh informasi melalui proses pengumpulan data, pengorganisasian data, dan analisis data yang ditempuh dengan teknik pengukuranstatistik,(4)Providing, mengandung arti menyelaraskan dan menyajikan informasi yang relevan dan berharga, (5) Useful, mengandung makna kemanfaatan dan kesesuaian untuk menentukan criteria yang diinginkan baik oleh evaluator maupun pemakai hasil evaluasi, (6) Information, adalah data deskriptif atau penafsiran data yang menggambarkan secara menyeluruh tentang hubungan antara komponen atau fenomena, (7) Judging, adanya pertimbangan bobot tentang nilai atau kriteria, dan (8) Decision alternatives, merupakan pilihan-pilihan respon terhadap berbagai kemungkinan kegiatan (action), berdasarkan hasil temuan yang diperoleh.

Menurut Stufflebeam yang dikutip oleh Popham mendeskripsikan bahwa ada empat jenis yang ditinjau dari jenis keputusan yang diambil, yaitu: (1) Evaluasi Konteks, menghasilkan "keputusan perencanaan atau planning decision", (2) Evaluasi Input, menghasilkan "keputusan penentuan strategi atau structuring decision", (3) Evaluasi Proses, menghasilkan "implementing decision", dan (4) Evaluasi Produk, menghasilkan "recycling decision". ${ }^{6}$

\section{Madrasah Tsanawiyah Satu Atap (MTs-SA)}

Madrasah Tsanawiyah-Satu Atap (MTsSA) adalah Madsarasah Tsanawiyah yang dibangun secara terpadu dengan Madrasah Ibtidaiyah, Diniyah/salafiyah atau satuan pendidikan sederajat di pondok Pesantren. Program pembangunan tersebut adalah dalam kerangka penuntasan Wajib belajar Pendidikan Dasar Sembilan Tahun.Tujuan

\footnotetext{
${ }^{6}$ W. James Popham. 1974. Educational Evaluation. Engelewood Clifts, New Jersey: Prentice Hal Inc. p. 45.
}

dari program Madsarasah Tsanawiyah Pesantren Satu atap (MTs-SA) adalah: (a) meningkatkan akses pendidikan dasar dalam rangka wajib belajar, melalui pembangunan Madsarasah Tsanawiyah Satu Atap (MTs-SA); (b) meningkatkan mutu pendidikan dasar di lingkungan Madrasah sesuai sistem pendidikan nasional; (c) meningkatkan partisipasi dan pemberdayaan masyarakat dalam pengelolaan pendidikan.Lingkup dan sasaran program Madsarasah Tsanawiyah Pesantren Satu atap (MTs-SA) adalah: (a) program diperuntukkan bagi pesantren yang memiliki MI atau satuan pendidikan formal sederajat di bawah Kemententerian Agama tapi belum memiliki MTs dan MIN; dan lulus dari sekolah ini tidak punya akses untuk melanjutkan belajarnya ( b) program mengutamakan kelompok masyarakat miskin dan kelompok yang kurang mendapatkan layanan pendidikan secara memadai (c) program pembangunan mencakup pengadaan gedung, ruang belajar dan ruang pendukung dan mobiler; (d) sasaran cakupan wilayah meliputi provinsi dan kabupaten/kota dan kecamatan (e) sasaran program pembangunan Madrasah mencakup lebih kurang 500 MTs-SA (f) seluruh sasaran akan dicapai dalam jangka waktu 2006-2009.

\section{Metode Penelitian}

Penelitian ini merupakan penelitian evaluasi dengan pendekatan kualitatif. Dan data yang bersifat kuantitatif akan dianalisis secara proporsional, sehingga gambaran tentang fenomena di lapangan dapat terungkap secara lebih baik.

Variabel yang diangkat dalam penelitian ini. 1) Pengembangan akses pendidikan; keberhasilan MTs-SA Sabilul Muttaqien dalam penyediaan layanan pendidikan, keterjangkauan layanan sosial, dan respon masyarakat; 2) Tata kelola; gambaran obyektif tentang kepemimpinan, kemadirian, dan transparansi yang terdapat di MTs-SA Sabilul Muttaqien; 3) Partisipasi masyarakat; tingkat keikutsertaan komponen masyarakat dalam 
mendukung program pendidikan pada MTs-SA Sabilul Muttaqien.

Penelitian ini dilakukan di MTs-SA Sabilul Muttaqien Desa Budagan, Kecamatan Pademawu, Kabupaten Pamekasan. Sedang waktu penelitian dilaksanakan pada bulan agustus 2011 selama 10 hari di lapangan.

\section{HASIL DAN PEMBAHASAN}

\section{Profil Madrasah Tsanawiyah satu atap (MTs-SA)}

Lembaga yang setara dengan madrasah Tsanawiyah di Kecamatan Pademawu sangat terbatas. Artinya tidak seimbang antara jumlah siswa dengan banyaknya lembaga pendidikan dasar baik MI maupun SD. Lembaga MTs yang setara dengan SMP yang ada di Kecamatan Pademawu Kabupaten Pamekasan masih sangat terbatas dan tidak seimbang dengan jumlah sekolah pendidikan tingkat dasar.

Madrasah Tsanawiyah satu atap secara umum dapat digambarkan sebagai berikut. MTs-SA pada umumnya terletak di lingkungan pesantren.Keberadaanyaini akanberpengaruh besar terhadap kesadaran masyarakat terhadap pendidikan.MTs-SA secarageografis diletakkan pada daerah pedesaan yang tertinggal dan jauh dari lembaga yang setara dengan SMP/MTs serta sosial ekonomi masyarakat yang rendah. Denan kondisi ini dapat diprediksi akan banyak masyarakat yang anaknya putus sekolah.

Selain itu MTs SA juga rata-rata mempunyai MI/SD pendukung baik internal maupun eksternal sehingga MTs-SA dipastikan dapat survive selama MI/SD internal/ekternal itu ada. MTs-SA Sabilul Muttaqien yang beralamat di desa budagan, Kec. Pademawu, Kab. Pamekasan dibangun pada tangggal 7 Aagustus 2007 dan gedungnya baru dapat ditempati pada tahun ajaran 2008.

\section{Pengembangan Akses Pendidikan}

Pelayanan proses pendidikan di MTsSA Sabilul Muttaqien difasilitasi dengan berbagai sarana yang sesuai dengan kebutuhan pendidikan. Kehadirannya di tengah masyarakat diapresiasi, Masyarakat, sebagai pihak konsumen pendidikan (esucational customer), menaruh harapan yang sangat besar terhadap pelaksanaan pendidikan yang bermutu. Berangkat dari hal tersebut MTsSA Sabilul Muttaqien merasa tertantang dan terpanggil untuk selalu berusaha dan bekerja keras meningkatkan pelayanan pendidikan dalam rangka menjamin mutu pendidikan yang diselenggarakannya. Sementara itu ketersedia fasilitas layananan di MTs-SA Sabilul Muttaqien masih terbatas dan jauh dari standar sesuai undang-undang system pendidikan nasional.

Tersedianya layanan di MTs-SA Sabilul Muttaqien dapat dibedakan menjadi dua indicator antara lain: sumber daya madrasah (SDM) dan sarana dan prasarana. MTs-SA Sabilul Muttaqien sudah mempunyai tenaga pendidik dan kependidikan terdiri dari Tenaga pendidik sebanyak 15 orang dan 2 staf yaitu KTU dan TU. Tenaga pendidik tersebut telah memiliki ijazah sarjana dan memiliki kompetensi di bidangnya. Sarana dan prasarana yang kini dimilki MTs-SA Sabilul Muttaqien yaitu:, (1) ruang belajar sebanyak 6 buah, (2). ruang osis 1 buah, (3) ruang bimbingan \& konsling (BK) satu buah, (4) ruang osis 1 buah dilengkapi juga meja dan kursinya, (5) ruang UKS 1 buah, (6) ruang laboratorium computer dan sains 1 buah, (7) ruang perpustakaan 1 buah, dan (8) jumlah buku penunjang 60 , buku pegangan gutu sebanyak 15 dan dan buku poko siswa tidak ada. Berdasarkan data-data tersebut, MTs-SA Sabilul Muttaqien, sementara ini hanya memiliki sarana fisik, dalam bentuk gedung dan ruangan-ruangan penunujang kegiatan proses belajar mengajar beserta meubellernya saja.

Dilihat dari keterjangkauan layanan (sosial dan geografis), MTs-SA Sabilul Muttaqien Desa Budagan terletak di desa yang sangat terpencil dan jauh dari perkotaan. Desa Budagan ini dikelilingi oleh empat desa yang berdekatan yaitu desa Banjarsari, Curah Rejo, Kenduruan, 
dan Wonokerto. Dari 4 desa ini rata-rata mempunyai sekolah tingkat dasar baik SDN/ MI antara $2 \mathrm{~s} / \mathrm{d} 3$ sekolah. Akan tetapi secara geografis yang bisa dijangkau oleh MTsSA Sabilul Muttaqien diperkirakan $8 \mathrm{~s} / \mathrm{d} 10$ lembaga pendidikan saja . Faktor jarak akan menjadi pertimbangan masyarakat, selain hemat biaya, masyarakat juga akan dengan mudah mengontrol anaknya pada masa proses belajar. 1) keprihatinan antara lain bahwa terjadinya kemerosotan moral bangsa diakibatkan oleh pergaulan bebas. Dengan menitipkan anaknya pada kiyai ada harapan anaknya menjadi anak yang baik/ sholeh yang berguna buat dirinya dan orang lain. 2) berangkat dari tuntutan dan perubahan zaman yang melaju begitu pesat. Pesantren yang melaksanakan pendidikan formal diharapkan bisa mengantarkan anaknya menghadapi tantangnagan zaman tersebut.

\section{Tata Kelola MTs-SA Sabilul Mutaqien}

Kepemimpinan kepala madrasah MTs-SA Sabilul Muttaqien adalah merupakan salah satu faktor yang menentukan dalam peningkatan mutu pendidikan di madrasah tersebut. Hal tersebut dapat dilihat dari upaya-upaya dan langkah-langkah kepala madrasah dalam mendorong serta memotivasi warga madrasah untuk mewujudkan visi, misi dan tujuan madrasah melalui program - program yang dilaksanakan secara terencana dan bertahap.

Dalam pada itu, kepala madrasah bertanggung jawab atas manajemen pendidikan secara mikro, yang secara langsung berkaitan dengan proses pembelajaran di MTs-SA Sabilul Muttaqien. Apa yang diungkapkan di atas menjadi lebih penting dengan semakin kompleknya tuntutan tugas kepala madrasah, yang menghendaki dukungan kinerja yang semakin efektif dan efisien. Kepala MTsSA Sabilul Muttaqien juga membangun tim work yang handal yang disesuaikan dengan kebutuhan. Tim tersebut terdiri dari wakilwakil kepala sekolah
Dari uraian tersebut di atas dapat disimpulkan bahwa kualitas kepemimpinan kepala madrasah merupakan salah satu faktor penentu keberhasilan dalam mencapai tujuan pendidikan. Ini berarti bahwa kinerja madrasah dapat dicapai melalui kepemimpinan kepala madrasah yang baik pula.

MTs-SA Sabilul Muttaqien sebetulnya dibentuk atas inisiatif masyarakat. Inisiatif tersebut kemudian direspon oleh yayasan/ pengasuh pondok walaupun tanpa modal apapun. Atas kerja keras dan keseriusan pengurus yayasan yang dibantu oleh masyarakat dalam mengelola pendidikan, yayasan kemudian mencoba berkomuknikasi dengan berbagai pihak yang dianggap mampu untuk bisa membantu lancarnya perjalanan pendidikan MTs-SA Sabilul Muttaqien tersebut.

Dengan kondisi seperti ini lembaga MTs-SA Sabilul Muttaqien berupaya untuk membangun usaha mandiri. Upaya yang dilakukan madrasah adalah meningkatkan partisipasi masyarakat dengan cara membentuk paguyauban kelas oleh semua wali murid dari masing-masing kelas (PAGU). Setelah pembentukan paguyuban kelas oleh wali murid masing-masing kelas, dilajutkan dengan pembentukan komite madrasah yang terdiri dari unsur perwakilan paguyuban kelas . Disitulah warga sekolah bersama-sama komite membuat program dalam rangka membantu dan menyukseskan program madrasah dan memediasi antara mayarakat dengan pihak madrasah.

MTs-SA Sabilul Muttaqien berupaya untuk melibatkatkan semua unsur pemangku kepentingan walaupun upaya yang dilakukan masih belum sempurna. Upaya tersebut dilakukan dalam rangka transparansi pendidikan melalui penataan 1) Mekanisme yang menjamin sistem keterbukaan dan standarisasi dari semua proses-proses pelayanan public dimadrasah, 2) Mekanisme yang memfasilitasi pertanyaan-pertanyaan terkait dengan kebijakan dan pelayanan publik, maupun proses-proses di dalam sektor 
publik. Keterbukaan madrasah atas berbagai aspek pelayanan publik, pada akhirnya akan membuat madrasah menjadi bertanggung gugat kepada semua pemangku kepentingan yang berkepentingan dengan proses maupun kegiatan dalam sector publik.

\section{Partisipasi Masyarakat}

Wujud nyata partisipasi masyarakat terhadap MTs-SA Sabilul Muttaqien dapat diidentifikasi ke dalam 2 bentuk, yaitu 1) partisipasi dalam bentuk menyekolahkan putra-putrinyan di MTs-SA Sabilul Muttaqien, dan 2) partisipasi dalam bentuk sumbangsih tenaga, pemikiran, saran dan kritik. Partisipasi orang tua siswa, dalam bentuk ini, disalurkan melalui kotak saran Ada juga orang tua siswa secara langsung menyampaikan keluhan dan masukannya kepada Kepala Madrasah. Namun ada juga yang menyampaikannya melalui guru wali kelas masing-masing.

Peran komite MTs-SA Sabilul Muttaqien dalam melaksnakan program-programnya masih belum tampak terlihat. Hal ini karena komite di MTs-SA Sabilul Muttaqien masih relative baru,dibentuk pada tanggal 28 maret 2010.

Dukungan dari lembaga lain ke MTs-SA Sabilul Muttaqien sangat besar, khususnya pemerintah. Dukungan pemerintah berupa pemberian izin pendirian madrasah, dan bantuan untuk mendapatkan ijin operasional sekolah (BOS). Selain itu, pemerintahjuga selalu pro aktif dalam memberi informasi berkaitan dengan pengembangan lembaga, baik dalam bentuk pelatihan, seminar, workshop dan lain-lain. Selain dukungan pemerintah, ormasormas dan LSM juga memberikan pemikiran, saran dan kritik yang sangat diperlukan bagi MTs-SA Sabilul Muttaqien dalam rangka berbenah dan mempercepat lajunya perkembangan madrasah.

\section{PENDAHULUAN}

\section{Kesimpulan}

1. Sarana utama lembaga MTs-SA Sabilul Muttaqien sudah cukup memadahi tetapi kelengkapannya belum ada sama sekali.

2. SDM MTs-SA Sabilul Muttaqien sudah tercukupi sesuai kebutuhan dan sesuai dengan kompetensinya. Manajemen MTsSA Sabilul Muttaqien sudah cukup tertata. Dari segi tansparansi, MTs-SA Sabilul Muttaqien sudah sangat transparan.

3. Wujud nyata partisipasi masyarakat terhadap MTs-SA Sabilul Muttaqien dalam bentuk menyekolahkan putra-putrinya di MTs-SA Sabilul Muttaqien dan sumbangsih tenaga, pemikiran, saran, dan kritik.

\section{Rekomendasi}

1. Perlu membantu pengadaan buku-buku pembelajaran baik pokok dan penunjang serta buku-buku koleksi perpustakaan.

2. Perlu membantu pengadaan alat peraga Lab SAINS dan perlangkapan laboratorium lainnya seperti laboraorium bahasa Arab dan bahasa Inggris.

3. Perlu membantu pengadaan alat kantor dan media/alat pembelajaran, seperti proyektor, LCD, TV dan audio visual lainnya.

4. Perlu mengevaluasi perkembangan MTsSA pada setiap tahun.

\section{SUMBER BACAAN}

Burhanudin, Jajat (2006): Mencetak Muslim Modern: Peta Pendidikan Islam di Indonesia. Jakarta, Raja Grafindo Persada.

Brinkerhoff, Robert O. et. el. (1983): Program Evaluation, A Practutioner's Guide For Trainers and Educators. Boston, KluwerNijhoff Publishing. 
Bruner, Jerome (1977): The Process of Education. Cambridge, Harvard University Press.

Djaali, Pudji Mulyono, dan Ramly (2004): Pengukuran Dalam Bidang Pendidikan. Jakarta, Program Pascasarjana Universitas Negeri Jakarta.

Departemen Agama RI (2007): Statistik Pendidikan Agama \& Pendidikan Keagamaan Tahun 2006-2007, Jakarta, Direktorat Pendidikan Islam Departemen Agama.

Departemen Pendidikan Nasional (2002): Panduan Monitoring dan Evaluasi. Jakarta, Departemen Pendidikan Nasional Dikdasmen Direktorat SLTP.

Fuad, Nurhattati (2008): "Madrasah Satu Atap: Sebuah Alternatif", Edukasi , Vol 6, Nomor 4, Oktober-Desember 2008

Grounlund, Norman E and Robert L. Linn (1990): Measurment and Evaluation in Teaching. New York, Mac Milan Publishing Company.
Mastuhu (1994): Dinamika Sistem Pendidikan Pesantren, Jakarta, INIS.

Mulyana, Deddy (2002): Metodelogi Penelitian Kualitatif. Bandung, Remaja Rosdakarya.

Musa, Saburi (2005): Evaluasi Program Pembelajaran Dan Pemberdayaan Masyarakat. Bandung, Y-Pin Indonesia.

Muhadjir, Noeng (2000): Metodologi Penelitian Kualitatif. Yogyakarta, Rake Serasin.

Moleong, Lexy J (2004): Metodelogi Penelitian Kualitatif. Bandung, Remaja Rosdakarya.

Popham, W. James (1981): Modern Educational Evaluation. New Jersey, Prenctice Hall Inc.

Pemerintah Australia dan Indonesia, Manual Program:Program Pendidikan Dasar Australia Indonesia, 12 Desember 2008, edisi Ketiga, Maret 2009, http:/www.bep.or.id

Undang-undang Nomor 20 Tahun 2003 tentang Sistem Pendidikan Nasional., Jakarta: BP Cipta Jaya, 2003 